Revista Brasil. Bot., V.33, n.1, p.13-20, jan.-mar. 2010

\title{
Pollen morphology of species of Hortia (Rutaceae)
}

\author{
MILTON GROPPO ${ }^{1,3}$, MARIA AMÉLIA VITORINO DA CRUZ-BARROS² and \\ ANGELA MARIA DA SILVA CORREA ${ }^{2}$
}

(received: January 17, 2008; accepted: October 28, 2009)

\begin{abstract}
Pollen morphology of species of Hortia (Rutaceae)). A palinological study covering all 10 species of the Neotropical genus Hortia Vand. (Rutaceae) was conducted. Pollen grains were collected from herbarium exsiccates, acetolysed and mounted in glycerine jelly on glass slides. The grains were studied under light and scanning electron microscopy, including measurements of polar and equatorial diameters, shape of the grains, number and shape of apertures, and thickness of the exine. The results demonstrated that the genus is stenopalynous, with pollen grains in monads, subprolate to prolate, 3-colporate, with very thick exine and a psilate-perforate pattern of ornamentation. Pollen grains of all species revealed a great similarity, with few variations in the pattern of ornamentation of exine, number and form of apertures and measurements. Although well-characterized palinologycally, pollen features did not furnish relevant information on the position of Hortia into an intrafamilial phylogeny.
\end{abstract}

Key words - Hortia, pollen, Rutaceae

RESUMO - (Morfologia polínica em espécies de Hortia (Rutaceae)). Um estudo palinológico de todas as 10 espécies do gênero neotropical Hortia Vand. (Rutaceae) foi realizado. Os grãos de pólen foram coletados de exsicatas de herbário, acetolisados e montados em lâminas com gelatina glicerinada. As observações incluíram medições dos diâmetros polar e equatorial, bem como do formato dos grãos de pólen, número e forma das aberturas e espessura da exina. Foram feitas fotomicrografias em microscopia óptica e em microscopia eletrônica de varredura. As análises mostraram que o gênero é estenopolínico, com grãos de pólen em mônades, subprolatos a prolatos, 3-colporados, com exina muito espessa e padrão de ornamentação psilado-perforado. Os grãos de pólen de todas as espécies mostraram grande similaridade, com poucas variações no padrão de ornamentação da exina, número e forma das aberturas e medidas. Apesar do gênero ser bem caracterizado palinologicamente, a morfologia do pólen não forneceu informações relevantes para posicionar Hortia em uma filogenia intrafamiliar.

Palavras-chave - Hortia, pólen, Rutaceae

\section{Introduction}

Hortia Vand. is a Neotropical genus of Rutaceae, traditionally included in subfamily Toddalioideae, subtribe Toddaliinae (Engler 1931). The 10 species are distributed from Panama to the state of São Paulo, Brazil; most of the species occur in Amazonian region. They are trees or shrubs with simple leaves crowded near the apices of the branches, showy, broad corymbose terminal inflorescences, reddish to pink flowers, and baccate fruit with abundant oil glands (Groppo 2004). The baccate fruit distinguishes Hortia from all the native genera of South-American Rutaceae.

Barth (1982) was the first author that studied the pollen of Hortia, in a publication with brief comments on

1. Universidade de São Paulo, Faculdade de Filosofia, Ciências e Letras de Ribeirão Preto, Departamento de Biologia, Av. Bandeirantes 3900, 14040-901 Ribeirão Preto, SP, Brazil.

2. Instituto de Botânica, Caixa Postal 3005, 01061-970 São Paulo, Brazil.

3. Author for correspondence: groppo@ffclrp.usp.br some species and genera of Brazilian Rutaceae. The same author also published three short articles characterizing some genera of Brazilian Rutaceae in a more detailed approach, such as Zanthoxylum (Barth 1980), Dictyoloma and Hortia (Barth 1983) and Pilocarpus (Barth 1985). Morton \& Kallunki (1993) carried out a detailed study evolving pollen of the species in the Neotropical subtribe Cuspariinae (= Galipeinae, see Kallunki \& Pirani 1998). They observed a great diversification in the pollen morphology among the species of the group. In the same work, they analyzed the pollen of three species of Hortia, whose transference from Englerian subfamily Toddalioideae to the tribe Cusparieae (= Galipeae, subfamily Rutoideae) had been suggested in the light of chemical similarities (Silva et al. 1988). However, the characteristics of the pollen of Hortia offered no support for the transference of this genus from Toddalioideae to the Galipeinae. On the other hand, new data from molecular cpDNA analysis have suggested a closer relationship of Hortia with Adiscanthus, a monospecific genus from Amazonia traditionally positioned in Galipeinae (Groppo et al. 2008). 
The objective of the present work is to study the pollen of all 10 species of Hortia, detailing the previous investigations of Barth (1982, 1983) and Morton \& Kallunki (1993), with a larger sample of species and specimens, searching for useful palinological characteristics that could be used in a phylogenetical analysis of the group.

\section{Material and methods}

All ten species of Hortia recognized in the revision of the genus (Groppo 2004) were analyzed: Hortia brasiliana Vand. ex DC., H. coccinea Spruce ex Engl., H. excelsa Ducke, H. longifolia Spruce ex Engl., H. neblinensis Maguire \& Boom, H. nudipetala Groppo, H. oreadica Groppo, Kallunki \& Pirani, H. regia Sandwith, H. superba Ducke, and $H$. vandelliana Groppo. The name $H$. oreadica refers here to a shrubby species of cerrado (Brazilian and Bolivian savannahs) commonly identified in herbaria as $H$. brasiliana, while the name $H$. brasiliana is applied here to an arborescent species best known as its synonymy $H$. arborea Engl. (see Groppo et al. 2005). A list with full references of vouchers is provided in the Material and methods section.

Pollen of all samples were collected from exsiccate deposited in public herbaria (vouchers listed below). Anthers from pre-anthesis buds were utilized only, since this procedure avoids contamination. One to five (seven in Hortia brasiliana) different specimen to each species were studied. One specimen of each species was chosen to the descriptions and photographs ("reference material"). Pollen of $H$. neblinensis, known only from its type collection (with very young buds) were observed in light microscopy (LM) only, but the grains were neither measured nor photographed, since they always collapsed after acetolysis.

Pollen grains were acetolysed according to the method described by Erdtman (1960), and then mounted in glycerine jelly on 3-5 glass slides to each specimen. Grains were observed and measured in an Olympus microscope with a ruler adapted to the ocular lens. The measurements were taken in a maximum of one-week period because the frequent inflating of the grains after some days, as reported in Melhem \& Matos (1972) and Salgado-Labouriau (1973). Measurements of both polar (P) and equatorial (E) diameters were taken in 25 pollen grains in the reference material. Other measurements, such as to apertures, endoapertures and thickness of the exine were taken in just 10 grains. The remnant material of each species (the "comparison material") had taken just 10 measures of $P$ and $\mathrm{E}$ diameters.

Measurements in the "reference" and "comparison" materials were used to define shape and size classes of pollen, according to definitions of Barth \& Melhem (1988). Photomicrographs of the grains in LM were obtained with an Olympus video camera connected to a Personal Computer.

Scanning Electron Microscopy (SEM) analyses were made using grains collected directly from dry anthers or from acetolysed grains stocked in glycerine. The acetolysed grains were washed in distilled water and dehydrated in an alcoholic series (50\%, 70\% 90\% and absolute alcohol). Pollen samples (non and acetolysed grains) were subsequently mounted on stubs and sputtered with gold. Electromicrographs were obtained from a Jeol JSM 840A-Scanning Microscope. Images in SEM were used to define the pattern of ornamentation of exine and apertures, according to the terminology of Barth \& Melhem (1988) and Punt et al. (2007).

Vouchers of the specimens used in this work (acronyms in agreement with Holmgren et al. 1990). s.n. = no number. Hortia brasiliana Vand. ex DC. BRAZIL. Bahia: Maraú, 3-VIII-1967, S.G. da Vinha 16 (CEPEC); Mucugê, $12^{\circ} 55^{\prime} 00^{\prime} \mathrm{S}, 41^{\circ} 18^{\prime} 04^{\prime \prime} \mathrm{W}, 14-\mathrm{VII}-1996$, H.P. Bautista et al. PCD3601 (SPF). Minas Gerais: Descoberto, 11-I-2001, R.M. Castro et al. 96F (SPF); Rio Vermelho, 19-VI-1985, Menandro 95 (CEPEC). São Paulo: Rodovia Bertioga-São Sebastião, 18-V-1972, H.M. de Souza s.n. (IAC22823). Colombia. Chocó: 32 km S of Quibdó, alt. 50 m, 8-I-1979, A. Gentry \& E. Renteria 23817 (MO). Panama. San Blas, $9^{\circ} 19^{\prime}$ N, 7855' W, 18-XI-1984, G. de Nevers 4294 (MO). H. coccinea Spruce ex Engl. Brazil. Amazonas: Rio Curicuariary, afluente do rio Negro, 16-XII-1931, A. Ducke s.n. (INPA50602). Venezuela. Amazonas: Ríos Pacimoni-Yatua, Casiquiare, 27-XI-1953, B. Maguire et al. 36657 (NY); idem, 27-XI-1953, B. Maguire et al. 36650 (NY); idem, 7-II-1954, B. Maguire et al. 37564 (NY). H. excelsa Ducke. Brazil. Amapá: Oiapoque, ca. $3^{\circ} 0^{\prime} \mathrm{N}, 51^{\circ} 30^{\prime} \mathrm{W}, 6-\mathrm{XII}-1984$, B.V. Rabelo \& R. Cardoso 2900 (HAMAB). Amapá, no locality, 1956, A. de Miranda-Bastos 2187 (RB); idem, no date, A. de MirandaBastos 235 (IAN). H. longifolia. Spruce ex Engl. Brazil. Amazonas: Manaus, Reserva Biológica de Campina, $2^{\circ} 60$ ' S, 6001' W, 30-IV-1996, C.A. Cid 11232 (INPA); margem esquerda do Rio Nhamundá, 8-VII-1975, S. Assumpção \& D. Coelho 78, (INPA); Manaus, Distrito Agropecuário, $2^{\circ} 24^{\prime} 26^{\prime \prime}-2^{\circ} 25^{\prime} 31^{\prime \prime} \mathrm{S}, 59^{\circ} 43^{\prime} 40^{\prime \prime}-59^{\circ} 45^{\prime} 50^{\prime \prime}$ O, ca. 50-125 m alt, 6-XII-1989, N.M.N. da Cunha et al. 300 (INPA); idem, Estrada Manaus-Itacoatiara 5-VII-1975, O.P. Monteiro \& F.C. Melo s.n. (INPA 50131); Porto Trombetas, 11-VI-1986, E. Soares 128 (INPA). H. neblinensis Maguire \& Boom. Brazil. Amazonas: Serra Pirapucu, ca. 1250 m, 26-I-1966 N.L. Silva \& U. Brazão 60881 (MG, type). H. nudipetala Groppo. Brazil. Amazonas: São Gabriel da Cachoeira, Igarapé Tiburaí, 22-XI-1987, H.C. Lima et al. 3278 (SPF, type); idem, Rio Uaupés 28-I to 20-II-1948, R.E. Schultes \& F. López 9687 (GH). H. oreadica Groppo, Kallunki \& Pirani. Brazil. Distrito Federal: Brasília, 7-IV-1984, V.R. de Albuquerque 11 (SPF). Goiás: Chapadão do Céu, Parque Nacional das Emas, $17^{\circ} 49^{\prime}-18^{\circ} 28^{\prime} \mathrm{S}, 52^{\circ} 39^{\prime} \mathrm{W}-53^{\circ} 10^{\prime} \mathrm{W}$, 6-IV-1999, M.A. Batalha 3179 (SPF); Cristalina, Serra dos Cristais, alt. 1060 m, 3-IV-1973, W.R. Anderson 8014 (MBM). Minas Gerais: Uberlândia, 7-II-1947, A. Macedo 944 (SP); idem, 14-IV-1981, G. Hatschbach 43860 (MBM). H. regia Sandwith. Guyana, Essequibo Island.-W. Demerara, $6^{\circ} 30^{\prime} \mathrm{N}$, $58^{\circ} 39^{\prime}$ W, alt. 0-15 m, 12-XII-1992, T.W. Henkel \& M. Chin 481 (NY); idem, Cuyuni-Mazaruni, Mazaruni River, $5^{\circ} 42^{\prime} \mathrm{N}$, 
60¹7' W, alt. 550-600 m, 29-XII-1989, L.J. Gillespie \& D.R. Smart 2924 (NY). H. superba Ducke. Brazil. Amazonas, Estrada Manaus-Itacoatiara 15-V-1972, A. Loureiro et al. s.n. (INPA35776); Manaus, 253' S, 59॰58' W, 20-XII-2001, $M$. Groppo et al. 950 (SPF); idem, 30-III-1978, M. Silva et al. 2343 (INPA); idem, 22-VI-1983, L. Coêlho 1981 (INPA); idem, Estrada Manaus-Caracaraí, 1976, D. Coêlho \& Cabral 787 (INPA). H. vandelliana Groppo. Brazil. Amazonas: São Paulo de Olivença, alto Rio Solimões, 25-XI-1986, C.A. Cid et al. 8538 (SPF, type).

\section{Results and discussion}

Our results have shown pollen grains in Hortia (figures 1-25) in monads, isopolar, 3-colporate, subprolate or prolate $(\mathrm{P} / \mathrm{E}=1.2-1.8)$, with medium to large size (35.8 $-68.3 \mu \mathrm{m})$, rectangular and rounded at the corners in equatorial view. The colpi are meridionally-aligned, invaginated, narrow and straight, with $1 / 2$ to almost $2 / 3$ of the polar diameter length, with sparse, polymorphic granules covering their surfaces. The endoapertures are lalongate, easy to be visualized at LM (figure 5). Pollen grains of all species presented a great morphological similarity, and the genus can be considered as stenopalynous. Measurements of diameters and $\mathrm{P} / \mathrm{E}$ ratio to the species are summarized in table 1; measurements of colpi and endoapertures are in table 2.

The exine has a psilate-perforate pattern of ornamentation, somewhat rugulose in some grains, with small, circular perforations (figures 1, 4-5, 7, 15$16,18-19,20$ and 25). The structure of the exine is columellate, tectate-imperforate with rare perforations. The tectum is well developed, corresponding to $c a .11 \%$ (Hortia excelsa, H. superba and H. vandelliana) to $17 \%$ (H. longifolia) of the thickness of exine (figure 23). The nexine $1(1.0-1.3 \mu \mathrm{m})$ and nexine $2(1.0-1.6 \mu \mathrm{m})$ represent $c a .60-70 \%$ of total exine, being thicker under and along the margins of the colpi, when compared with its thickness in the mesocolpium region. The nexine is apparently always thicker than sexine.

The samples of Hortia regia (figure 20) presented the smallest pollen grains (polar diameter), with 37.0 to $41.9 \mu \mathrm{m}$ (means of two specimens analyzed). A specimen of H. nudipetala (Schultez \& López 9687) presented the largest pollen grains (mean of $64.6 \mu \mathrm{m}$ to P). Nevertheless, when the measurements of all species are compared, $\mathrm{P}$ and $\mathrm{E}$ values largely overlap, as well the $\mathrm{P} / \mathrm{E}$ ratio (see table 1). Barth (1983), using the statistically largest pollen dimensions (polar diameter, P), grouped the five species of Hortia analyzed in two pollen subtypes: Hortia coccinea and $H$. superba, with grains of medium size, and $H$. arborea $(H$. brasiliana here), H. brasiliana (H. oreadica here) and H. longifolia, with larger ones. These two groups could correspond well with the gross morphology of flowers: $H$. coccinea, $H$. superba, and other Amazonian species such as $H$. excelsa, $H$. neblinensis, and $H$. regia have flowers with petals without a prominent mid vein, these with smooth (non ornamented) trichomes distributed on all adaxial surface of the petals, while $H$. arborea and $H$. oreadica (plus $H$. vandelliana and $H$. nudipetala) bear flowers with a prominent mid vein on the adaxial surface of the petals, these with smooth trichomes (absent in $H$. nudipetala), and restricted as a tuft on the base on the adaxial surface. However, the use of a larger sample of species and specimens in this study, when compared with those presented in Barth (1983), apparently do not support her delimitation in two subtypes on basis of measurements of polar diameter, given the overlap in this value as verified here.

Our measurements to $\mathrm{P}$ and $\mathrm{E}$ diameters differ from those of Morton \& Kallunki (1993), which presented smaller values of $\mathrm{P}$ when compared with the present study (29.3-42.8 $\mu \mathrm{m}$ in three species analyzed, against 35.8-68.3 $\mu \mathrm{m}$ here). These differences in $\mathrm{P}$ are maintained even with the use of same two collections in both studies (Rabelo \& Cardoso 2900 and Hatschbach 43860, respectively Hortia excelsa, and H. oreadica). In these two cases, $\mathrm{P}$ values are $30-45 \%$ smaller in Morton $\&$ Kallunki (1993) than verified here, affecting the $\mathrm{P} / \mathrm{E}$ ratio (that defines the shape of the pollen). These discrepancies can arise because different ways in the preparation of grains, the use of different criteria in the measurements (use of a program to make the measurements or not), and because optical phenomenon like light diffraction.

The length of colpi and endoaperture are shorter in Hortia regia (figure 20), and longer in H. nudipetala (figure 13) and $H$. vandelliana (figure 24), presenting a variation of almost $100 \%$ between these two extremes. Other measurements, such as colpus and endoaperture width presented great variations between the specimens analyzed (see table 2). The results on the length of nexine 1 and 2 (here they are almost equal in size to all species) are very different of those verified in Barth (1983). In that study nexine 1 is always 4-5 times larger than nexine 2 (table 2, figure 23). This discrepancy can be credited, again, mainly to light diffraction in LM, and different criteria in the delimitation of the layers. Barth (1983) commented that nexine 2 in Hortia is very thin, but dense, and measurements using LM can be increased values because the light diffraction. The values of the exine layers are very constant to all species, and 

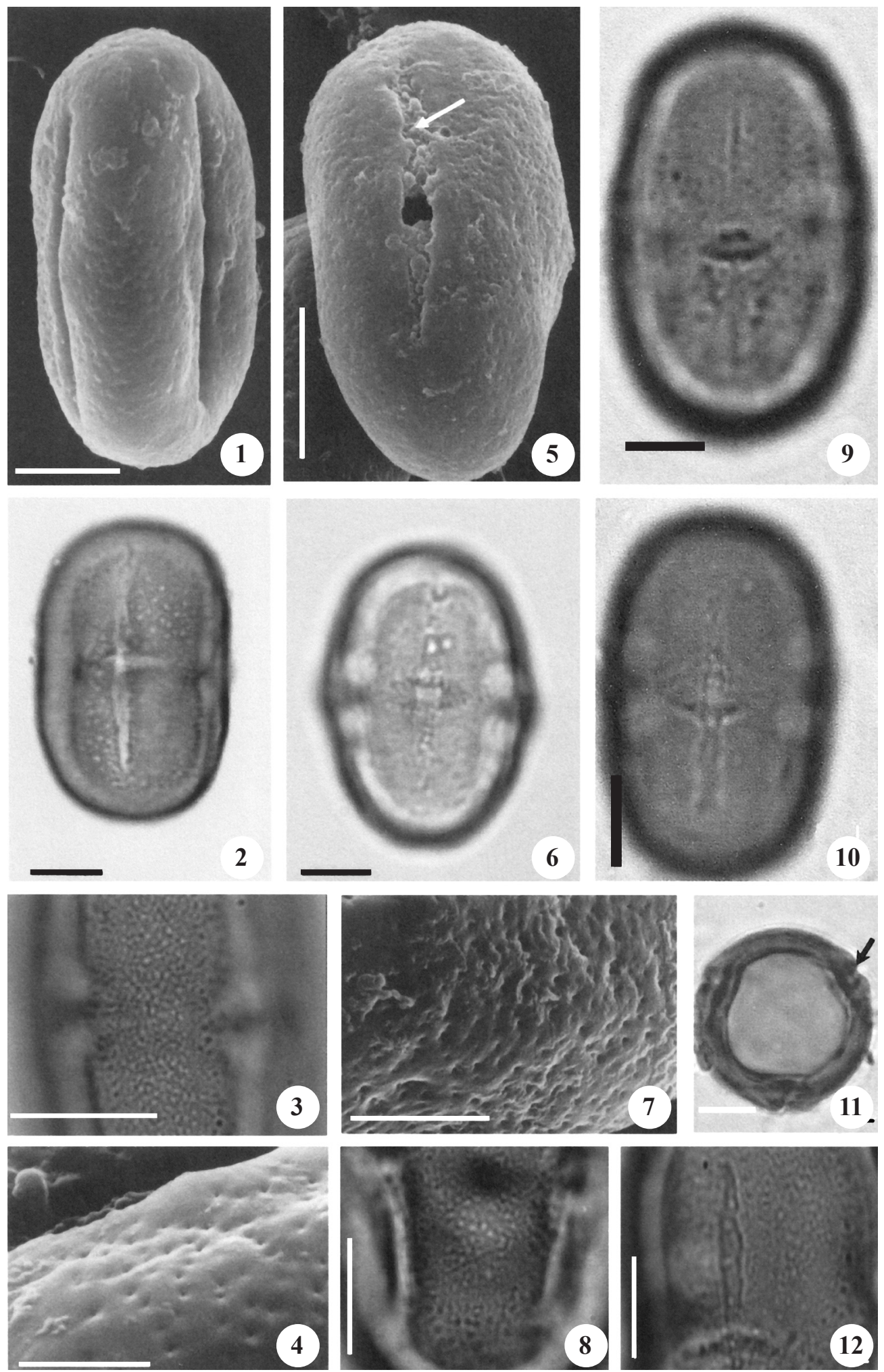

Figures 1-12. Pollen of Hortia. 1-4. H. brasiliana (from Castro 96F). 1. Equatorial view in SEM. 2. Equatorial view in LM. 3. Detail of mesocolpium in LM. 4. Detail of mesocolpium in SEM. 5-7. H. coccinea (from Ducke s.n., INPA50602). 5. Equatorial view in SEM; note the polymorphic granules in the colpus (arrow). 6. Equatorial view in LM. 7. Detail of the ornamentation of exine in SEM. 8-9. H. excelsa (from Rabelo \& Cardoso 2900). 8. Mesocolpium in LM. 9. Equatorial view in LM. 10-12. H. longifolia (from Cid et al. 11232). 10. Equatorial view in LM. 11. Polar view, showing 3 apertures, one of which indicated (arrow) in LM. 12. Mesocolpium and part of a colpus in LM. Bars $=10 \mu \mathrm{m}(1-3,5-6,8-12) ; 5 \mu \mathrm{m}(4,7)$. 
Table 1. Measurements of the Polar (P) and Equatorial (E) diameters in the species of Hortia analyzed. $(()=$ Mean; $n=$ Number of grains upon which the measurements of the diameters were made. The first sample of each species is the reference material. $\mathrm{P} / \mathrm{E}=$ ratio between mean of Polar diameter/Equatorial diameter values).

\begin{tabular}{|c|c|c|c|c|}
\hline Species and samples & $n$ & $\begin{array}{c}\text { Polar diameter }(\mathrm{P}) \\
(\mu \mathrm{m})\end{array}$ & $\begin{array}{l}\text { Equatorial diameter }(\mathrm{E}) \\
\qquad(\mu \mathrm{m})\end{array}$ & $\mathrm{P} / \mathrm{E}$ \\
\hline \multicolumn{5}{|l|}{ H. brasiliana } \\
\hline 1 Castro $96 F$ & 25 & $42.3-(45.8)-49.5$ & 23.9-(26.9-)29.1 & 1.7 \\
\hline 2 Souza s.n. (IAC22823) & 10 & 39.8-(43.7)-51.9 & $29.5-(31.5)-35.6$ & 1.4 \\
\hline 3 Menandro 95 & 10 & $48.1-(49.3)-51.9$ & $30.0-(31.7)-33.9$ & 1.6 \\
\hline 4 Vinha 16 & 10 & $51.1-(54.3)-57.7$ & $32.8-(34.8)-37.5$ & 1.6 \\
\hline 5 Bautista PCD3601 & 10 & 43.9-(46.9)-50.5 & $28.9-(30.6)-32.5$ & 1.5 \\
\hline 6 Nevers 4294 & 10 & $46.2-(47.8)-50.0$ & $30.0-(31.3)-32.8$ & 1.5 \\
\hline 7 Gentry \& Renteria 23817 & 10 & $52.8-(55.1)-58.1$ & $33.8-(36.1)-39.2$ & 1.5 \\
\hline \multicolumn{5}{|l|}{ H. coccinea } \\
\hline 1 Ducke s.n. (INPA50602) & 25 & $42.8-(45.1)-50.3$ & 28.0-(29.7)-32.7 & 1.5 \\
\hline 2 Maguire 37584 & 10 & $46.6-(48.8)-50.5$ & 25.3-(27.3)-29.5 & 1.8 \\
\hline 3 Maguire 36657 & 10 & 43.6-(44.9)-46.6 & 23.9-(25.3)-26.1 & 1.8 \\
\hline 4 Maguire 36650 & 10 & $42.7-(44.3)-45.8$ & $24.2-(25.6)-26.9$ & 1.7 \\
\hline \multicolumn{5}{|l|}{ H. excelsa } \\
\hline 1 Rabelo \& Cardoso 2900 & 25 & $48.3-(52.0)-54.1$ & $30.2-(33.1)-36.4$ & 1.6 \\
\hline 2 Miranda-Bastos 235 & 10 & 48.7-(49.8)-51.6 & $33.9-(35.7)-36.7$ & 1.4 \\
\hline 3 Miranda-Bastos 2187 & 10 & $48.7-(50.4)-53.4$ & $32.7-(34.8)-36.6$ & 1.4 \\
\hline \multicolumn{5}{|l|}{ H. longifolia } \\
\hline 1 Cid 11232 & 25 & $44.5-(46.9)-48.6$ & $30.6-(34.1)-48.1$ & 1.4 \\
\hline 2 Assunção \& Coelho 78 & 10 & $43.3-(44.9)-46.3$ & $29.1-(31.2)-33.8$ & 1.4 \\
\hline 3 Cunha 300 & 10 & $46.2-(49.2)-51.2$ & $31.9-(34.5)-35.5$ & 1.2 \\
\hline 4 Monteiro \& Mello s.n. (INPA50131) & 10 & $45.3-(47.6)-50.0$ & $30.3-(31.5)-32.3$ & 1.5 \\
\hline 5 Soares 128 & 10 & $44.1(45.5)-48.4$ & 29.4-(30.5)-31.4 & 1.5 \\
\hline \multicolumn{5}{|l|}{ H. nudipetala } \\
\hline 1 Lima et al. 3248 & 25 & $52.3-(54.9)-57.8$ & $28.7-(30.8)-32.2$ & 1.8 \\
\hline 2 Schultes \& López 9687 & 10 & $60.8-(64.6)-68.3$ & $38.4-(39.7)-42.5$ & 1.6 \\
\hline \multicolumn{5}{|l|}{ H. oreadica } \\
\hline 1 Batalha 3179 & 25 & $43.1-(46.1)-49.1$ & $24.7-(26.8)-28.3$ & 1.7 \\
\hline 2 Macedo 944 & 10 & $47.0-(49.7)-53.9$ & $28.3-(30.7)-32.8$ & 1.6 \\
\hline 3 Albuquerque 11 & 10 & $46.4-(50.5)-54.4$ & $30.8-(34.3)-41.4$ & 1.5 \\
\hline 4 Anderson 8014 & 10 & $52.3-(52.3)-57.0$ & $33.1-(35.5)-40.5$ & 1.5 \\
\hline 5 Hatschbach 43860 & 10 & $44.1-(46.6)-47.5$ & $27.2-(28.2)-29.7$ & 1.6 \\
\hline \multicolumn{5}{|l|}{ H. regia } \\
\hline 1 Henkel \& Chin 481 & 25 & 37.6-(41.9)-43.8 & $27.0-(30.0)-35.8$ & 1.4 \\
\hline 2 Gillespie \& Smart 2924 & 10 & $35.8-(37.0)-39.1$ & 29.8-(30.1)-32.0 & 1.2 \\
\hline \multicolumn{5}{|l|}{ H. superba } \\
\hline 1 Loureiro s.n. (INPA35776) & 25 & $54.1-(58.8)-61.9$ & $30.8-(33.8)-37.3$ & 1.7 \\
\hline 2 Groppo 950 & 10 & $50.6-(53.4)-55.0$ & $30.9-(32.8)-34.4$ & 1.6 \\
\hline 3 Silva 2343 & 10 & $46.3-(49.5)-52.5$ & $26.2-(29.9)-34.7$ & 1.7 \\
\hline 4 Coelho 1981 & 10 & $43.3-(45.6)-48.7$ & $24.5-(26.3)-27.3$ & 1.7 \\
\hline 5 Coelho \& Cabral 787 & 10 & $46.7-(48.7)-52.0$ & $27.0-(30.3)-32.8$ & 1.6 \\
\hline \multicolumn{5}{|l|}{ H. vandelliana } \\
\hline 1 Cid et al. 8538 (type) & 25 & $55.8-(59.7)-63.4$ & $32.8-(35.8)-38.1$ & 1.7 \\
\hline
\end{tabular}



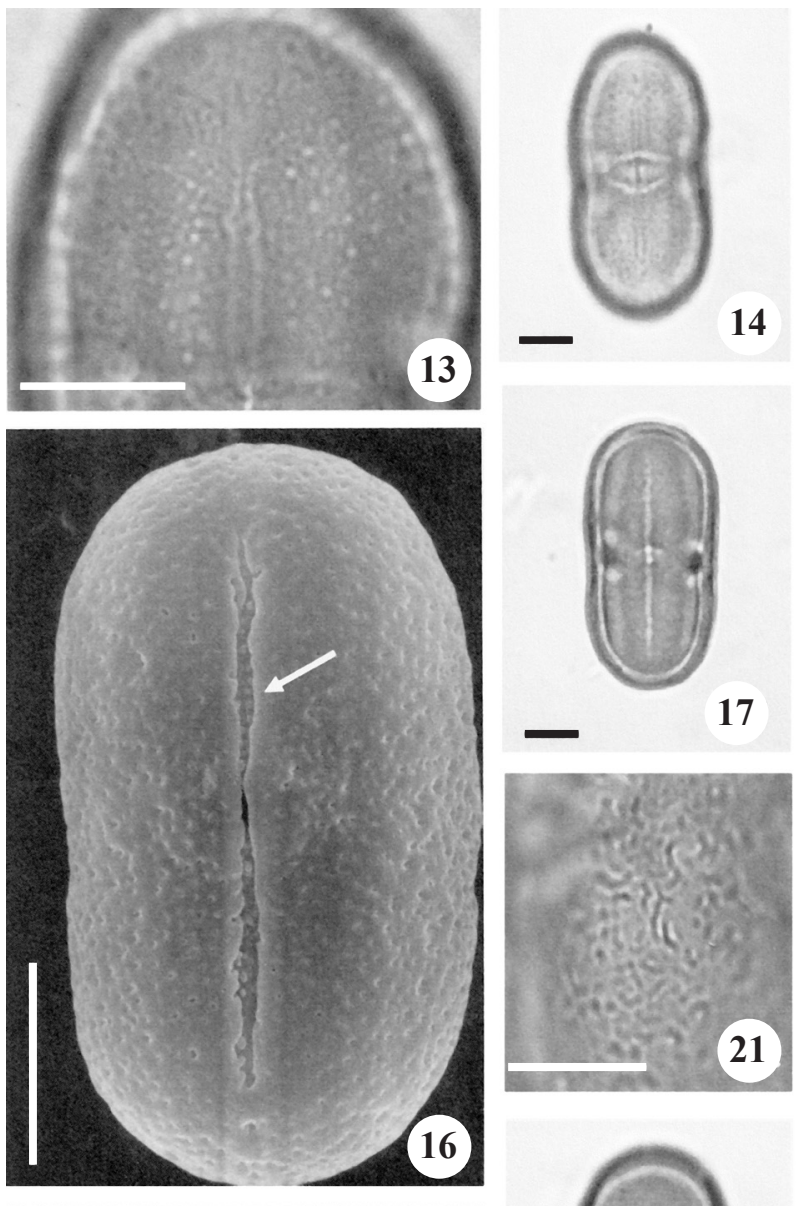

17
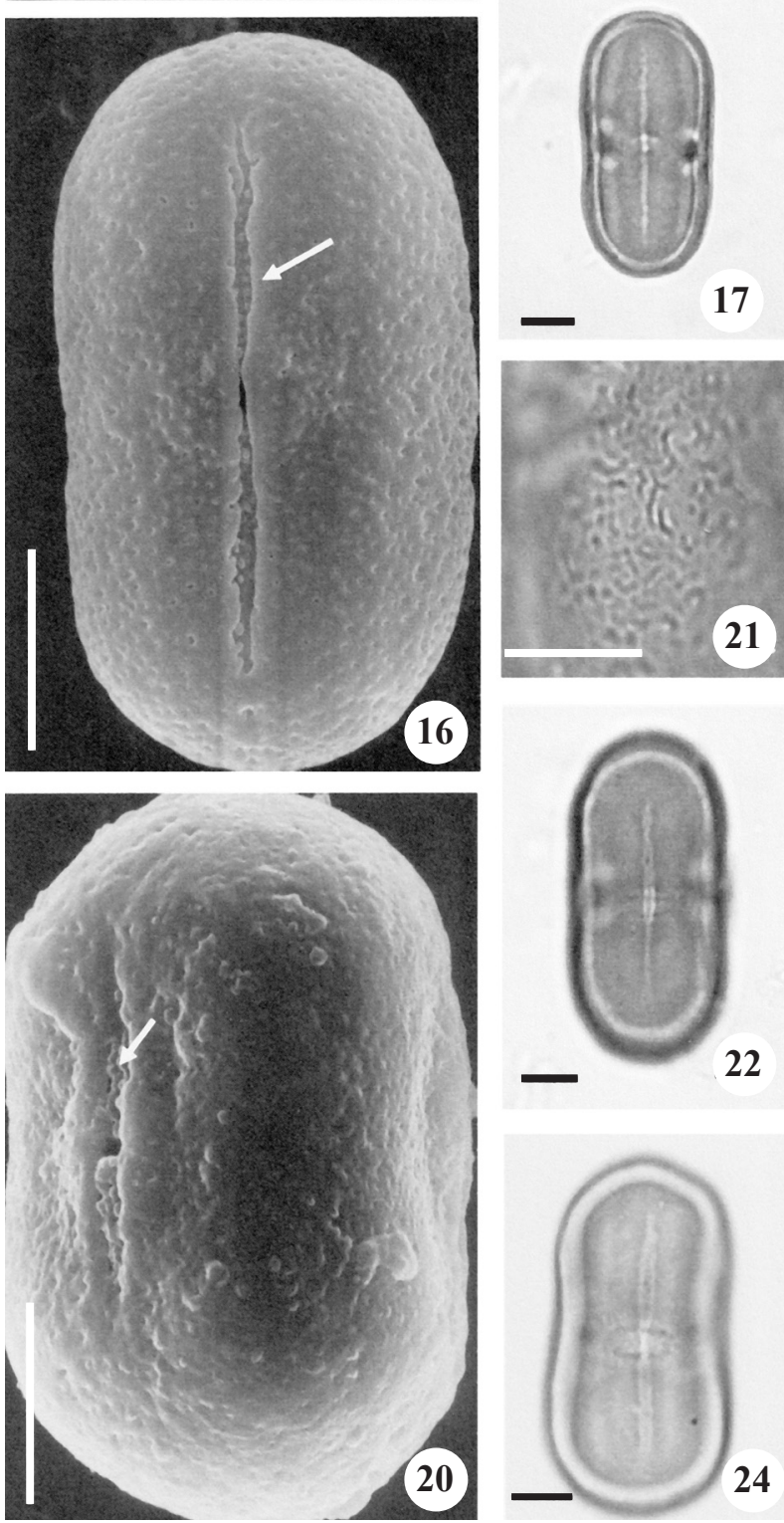

22

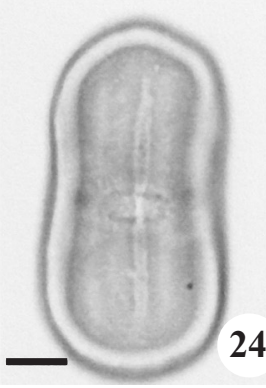

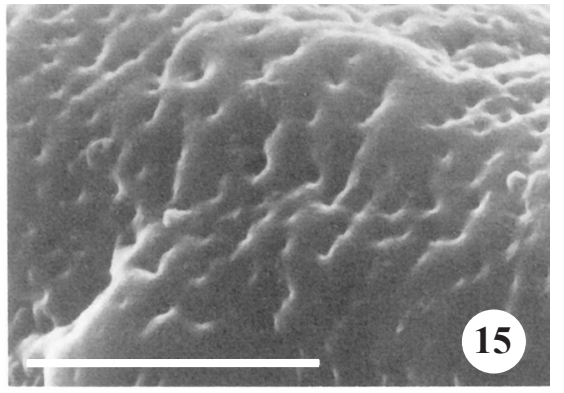
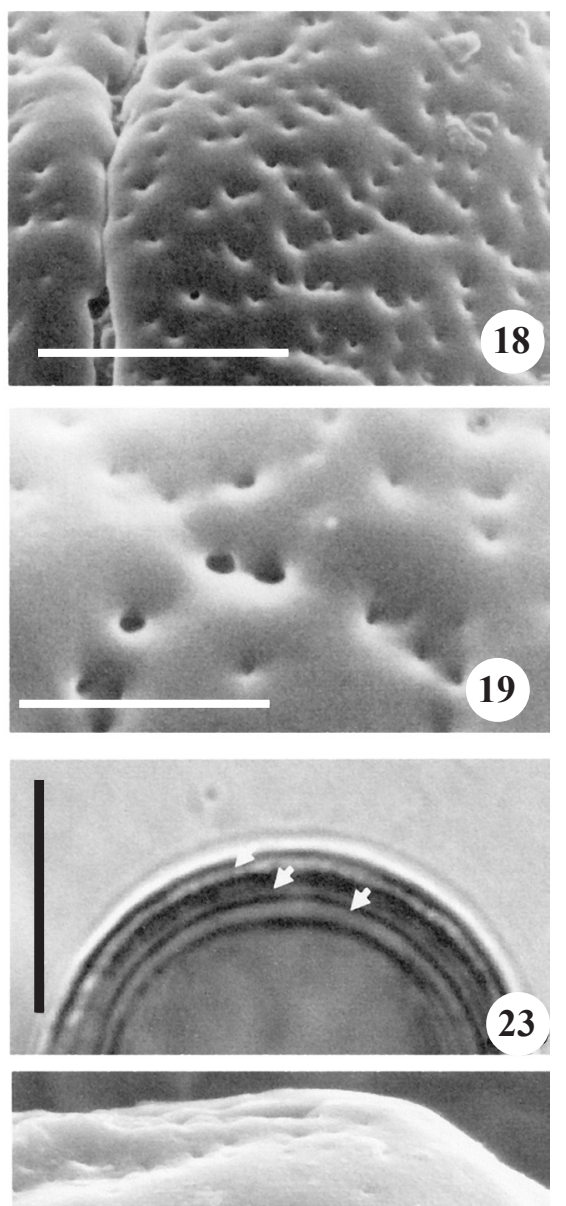

24

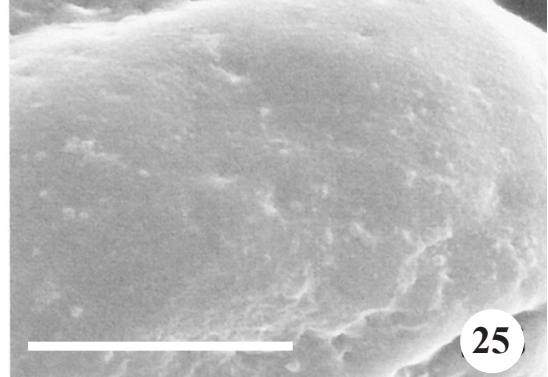

Figures 13-25. Pollen of Hortia. 13-15. H. nudipetala (from Lima et al. 3248). 13. Colpus and mesocolpium in LM. 14. Equatorial view in LM. 15. Detail of ornamentation of exine in SEM. 16-19. H. oreadica (from Batalha 3179). 16. Equatorial view in SEM, note narrow colpus (arrow). 17. Equatorial view in LM. 18. Ornamentation of exine in detail and part of a colpus in SEM. 19. Detail of the circular lumina. 20-21. H. regia (from Henkel \& Chin 481). 20. Equatorial view in SEM, note shorter colpus (arrow). 21. Mesocolpium in LM. 22-23. H. superba (from Loureiro s.n., INPA 35776). 22. Equatorial view in LM. 23. Optical section of exine, arrows showing (out to in) sexine, nexine 1 and nexine 2. 24-25. H. vandelliana (from Cid et al. 8538). 24. Equatorial view in LM. 25. Ornamentation of exine in detail in SEM. Bars $=10 \mu \mathrm{m}(13-14,16-17,20-25) ; 5 \mu \mathrm{m}$ $(15,18) ; 2 \mu \mathrm{m}(19)$. 
Table 2. Measurements (means) of colpi, endoapertures and exine (reference materials) in the species of Hortia analyzed. All measurements in $\mu \mathrm{m}$.

\begin{tabular}{|c|c|c|c|c|c|c|}
\hline \multirow{2}{*}{ Species } & \multirow{2}{*}{$\frac{\text { Colpus }}{\text { length } \times \text { width }}$} & \multirow{2}{*}{$\begin{array}{l}\text { Endoaperture } \\
\text { length } \times \text { width }\end{array}$} & \multicolumn{4}{|c|}{ Exine } \\
\hline & & & tectum & sexine (total) & nexine 1 & nexine 2 \\
\hline H. brasiliana & $33.0 \times 2.2$ & $2.5 \times 9.7$ & 0.5 & 1.4 & 1.1 & 1.1 \\
\hline H. coccinea & $29.3 \times 2.8$ & $3.8 \times 8.7$ & 0.5 & 1.2 & 1.0 & 1.0 \\
\hline H. excelsa & $30.0 \times 2.1$ & $3.8 \times 7.7$ & 0.5 & 1.8 & 1.4 & 1.5 \\
\hline H. longifolia & $28.5 \times 2.5$ & $4.3 \times 10.5$ & 0.6 & 1.3 & 1.0 & 1.3 \\
\hline H. nudipetala & $38.7 \times 2.0$ & $4.6 \times 12.7$ & 0.6 & 1.5 & 1.3 & 1.2 \\
\hline H. oreadica & $32.6 \times 1.6$ & $3.1 \times 8.2$ & 0.5 & 1.3 & 1.3 & 1.2 \\
\hline H. regia & $20.8 \times 1.8$ & $2.0 \times 6.0$ & 0.6 & 1.4 & 1.1 & 1.1 \\
\hline H. superba & $39.1 \times 2.2$ & $4.0 \times 10.5$ & 0.7 & 1.6 & 1.3 & 1.1 \\
\hline H. vandelliana & $39.2 \times 2.3$ & $4.1 \times 8.0$ & 0.5 & 1.4 & 1.3 & 1.6 \\
\hline
\end{tabular}

impossible to define infragenerical groups. According to Barth (1983) the surface pattern in the exine of Hortia arborea $(=H$. brasiliana) and H. longifolia are the same; H. superba, with more "puncta" (lumina here) per surface unit and H. brasiliana (H. oreadica here), with larger and numerous puncta. However, these details are hard to define and were not observed in the species analyzed, not justifying a pollen classification at species level. Hortia neblinensis, observed in LM only, showed the same pattern in the ornamentation of exine.

The exine in Hortia, characterized by a psilateperforate ornamentation with rare circular perforations and a well developed tectum is different from all genus of Rutaceae analyzed so far (figures 1, 4-7, 15-16, 18-20, 25). In Rutaceae the most common pattern of ornamentation is the reticulate one (according to a survey of Morton \& Kallunki 1993), which is widespread in the family and can occur in not so close phylogenetically related groups. Some genera included in subtribe Toddaliinae studied by Erdtman (1972), such as Sargentia (= Casimiroa) and Skimmia, presented striate-reticulate (in LM) pollen grains, different of those encountered in Hortia. However, this subtribe and the subfamily Toddalioideae as a whole (as circumscribed by Engler 1931) enclose baccate-fruited genera from different continents, being polyphyletic based mainly on data from secondary metabolites (e.g. Silva et al. 1988) and molecular analysis (Chase et al. 1999, Scott et al. 2000, Groppo et al. 2008). The findings of Groppo et al. (2008) have demonstrated that Hortia is close to other genera of the Neotropical Rutaceae, as the monospecific Adiscanthus (Galipeinae, subfamily Rutoideae), from Brazilian Amazonia. However, pollen grains in this genus are reticulate (Morton \& Kallunki 1993), while perforate grains can be found in Euxylophora (Barth 1982, Morton \& Kallunki 1993) and Rauia (Morton \& Kallunki 1993), both also from Galipeinae. These two later genera possess grains with frequent lumina, and not infrequently perforate like in Hortia. Although molecular data from Groppo et al. (2008) could suggest a closer relationship between Hortia and other Neotropical genera of Rutaceae, such as from the subtribe Galipeinae, data from pollen appear do not furnish useful information on the positioning of Hortia into an infra-familial phylogeny.

Acknowledgements - The authors is greatly indebted with the curators of the herbaria on loan of exsiccate and permission in study pollen grains from them; with Dr. Pedro K. Kiyohara (Laboratory of Microscopy, Instituto de Física, Universidade de São Paulo) for the use of scanning electron microscopy and precious information; with Simone P. Toledo, for her assistance and patience in taking images and photographs in SEM; and with Victor Martins Gonçalez for his help in editing the pollen images. This work was supported by Fapesp (Fundação de Amparo à Pesquisa do Estado de São Paulo) grants (\#00/07401-0, and 06/03170-0).

\section{References}

BARTH, O.M. 1980. Pollen morphology of Brazilian Rutaceae: Zanthoxylum (Fagara). Pollen et Spores 22:425-436.

BARTH, O.M. 1982. Variações polínicas em espécies brasileiras da família Rutaceae. Boletim do Instituto de Geociências da Universidade de São Paulo 13: 129-134.

BARTH, O.M. 1983. Pollen morphology of Brazilian Rutaceae: Dictyoloma and Hortia. Pollen et Spores 24:409-420. 
BARTH, O.M. 1985. Pollen morphology of Brazilian Rutaceae: Pilocarpus. Pollen et Spores 27:145-154.

BARTH, O.M. \& MELHEM, T.S. 1988. Glossário Ilustrado de palinologia. Editora da Unicamp, Campinas.

CHASE, M.W., MORTON, M.M. \& KALLUNKI, J.A. 1999. Phylogenetic relationships of Rutaceae: a cladistic analisys of the subfamilies using evidence from rbcL and atpB sequence variations. American Journal of Botany 86:1191-1199.

ENGLER, H.G.A. 1931. Rutaceae. In Die natürlichen Pflanzenfamilien (H.G.A. Engler \& K. Prantl, eds.). Leipzig. Wilhelm Engelmann, v.19a, ed. 2, p.187359.

ERDTMAN, G. 1960. The acetolysis method: a revised description. Svensk Botanisk Tidskrift 54:561-564.

ERDTMAN, G. 1972. Pollen morphology and plant taxonomy. Hafner Publishing Company, New York.

GROPPO, M. 2004. Filogenia de Rutaceae e revisão de Hortia. Tese de doutorado, Universidade de São Paulo, São Paulo.

GROPPO, M., KALLUNKI, J.A. \& PIRANI, J.R. 2005. Synonymy of Hortia arborea with $H$. brasiliana (Rutaceae) and a new species from Brazil. Brittonia 57:28-34.

GROPPO, M., PIRANI, J.R., SALATINO, M.L.F, BLANCO, S.R. \& KALLUNKI, J.A. 2008. Phylogeny of Rutaceae based on two non-coding regions from cpDNA. American Journal of Botany 95:985-1005.
HOLMGREN, P.K., HOLMGREN, N.H. \& BARNETT, L.C. 1990. Index herbariorum. Part I: the Herbaria of the World. New York Botanical Garden. Bronx, New York.

KALLUNKI, J.A \& PIRANI, J.R. 1998. Synopsis of Angostura Roem. \& Schult. and Conchocarpus J.C. Mikan (Rutaceae). Kew Bulletin 53:257-334.

MELHEM, T.S. \& MATOS, M.E.R. 1972. Variabilidade de forma nos grãos de pólen de Eriope crassipes Benth. - Labiatae. Hoehnea 2:1-10.

MORTON, C.M. \& KALLUNKI, J.A. 1993. Pollen morphology of the subtribe Cuspariinae (Rutaceae). Brittonia 45:286-314.

PUNT, W., HOEN, P.P., BLACKMORE, S. NILSSON, S. \& LE THOMAS, A. 2007. Glossary of pollen and spores terminology. Review of Palaeobotany and Palynology 143:1-81.

SALGADO-LABOURIAU, M.L. 1973. Contribuição à Palinologia dos cerrados. Academia Brasileira de Ciências, Rio de Janeiro.

SILVA, M.F.G.F., GOTTLIEB, O.R. \& EHRENDORFER, F. 1988. Chemosystematics of the Rutaceae: suggestions for a more natural taxonomy and evolutionary interpretation of the family. Plant Systematics and Evolution 161:97-134.

SCOTT, K.D., MCINTYRE, C.L. \& PLAYFORD, J. 2000. Molecular analyses suggest a need for a significant rearrangement of Rutaceae subfamilies and a minor reassessment of species relationships within Flindersia. Plant Systematics and Evolution 223:15-27. 